\title{
Ocalić pamięć, ocalić duszę, ocalić sztukę - o zbawiennej roli muzyki Fryderyka Chopina $w$ Pianiście Romana Polańskiego
}

We wczesnych latach swojej twórczości Roman Polański „posługiwał się" muzyką klasyczną[1] w sposób niezwykle ostrożny. Fragmenty Eine kleine Nachtmusik Mozarta, wplecione i poddane modyfikacjom, w ścieżce dźwiękowej Lampy (1958) oraz subtelne pierwsze nuty Dla Elizy Beethovena, tworzące nastrój scen w Diamentowym naszyjniku (1964) i Dziecku Rosemary (1968), to najpewniej tylko delikatne zasygnalizowanie, że autor Pianisty z jednej strony muzykę klasyczną ceni, z drugiej - nie ma jednak dostatecznej pewności, czy potrafi ją twórczo wykorzystać. Stąd, dość asekuracyjnie, Polański pozwala wybrzmiewać dziełom Mozarta i Beethovena - zarówno w kontekście znaczenia samej muzyki, jak i natężenia dźwięku - jedynie w bardzo odległym planie warstwy audialnej swoich filmów.

Nie można nie zacytować Bohdana Pocieja, który znakomicie uchwycił problem funkcjonowania muzyki klasycznej w filmie:

Ten modus czy styl muzyki filmowej - polegający na dobieraniu jej z gotowych zasobów bynajmniej dla filmu nie przeznaczonych $-\mathrm{z}$ pozoru łatwy, bezproblemowy, wymaga szczególnego wyczulenia na walory ekspresywno-symboliczne muzyki; wymaga po prostu wielkiej kultury muzycznej - poczucia smaku i taktu. Muzyka bowiem - ta wielka, wybitna, brana ze skarbca klasyki dla ilustracji brzmieniowej czy kontrapunktu dźwiękowego do słów, akcji, zdarzeń - to materiał sam w sobie niesłychanie czuły i delikatny; nietrudno tu o wypaczenie: sentymentalizm, patetyczną przesadę, fałszywą sytuację muzyki samej - jeśli znajdzie się w rękach reżysera o przeciętnym talencie i niedostatecznym smaku[2].

W roku 1972 Polański kręci - uznawany przez wielu za najsłabszy w jego dorobku - film Co? Jest to pierwszy, a zarazem jedyny w całej twórczości autora Matni, film pełnometrażowy, w którym rozbrzmiewa

[1] Termin „muzyka klasyczna” - bardzo skądinąd pojemny semantycznie - stosowany będzie w niniejszym szkicu nie tylko w odniesieniu do muzyki okresu klasycyzmu (Mozart, Beethoven), ale również romantyzmu (Schubert, Chopin). Problem owej spuścizny muzycznej wielkich mistrzów w kontekście teoretycznych rozważań dobrze uchwycił Carl Dahlhaus: „Nie tylko z historycznoliterackiego, lecz i estetycznego punktu widzenia to, co dawne, i to, co nowe,

\section{Images}

vol. XVII/no. 26

Poznań 2015

ISSN 1731-45OX 
tylko i wyłącznie muzyka klasyczna. Wykorzystując fragmenty zaledwie trzech utworów trzech wielkich klasyków: Mozarta, Schuberta i Beethovena, Polański tworzy barwny, nieco odrealniony świat, w którym muzyka klasyczna stanowi już coś więcej niż tylko tło. Bardzo często funkcjonuje ona na zasadzie - wspomnianego przez Bohdana Pocieja - kontrapunktu dźwiękowego, pełni wiele funkcji dramaturgicznych, a także wprowadza do filmu treści pozamuzyczne, ważne dla fabuły, a wynikające z programowego charakteru poszczególnych utworów - sonata Księżycowa (No 14 cis-moll, op. 27/2, Mondscheinsonate) Beethovena oraz Kwartet d-moll (D 810) Schuberta bardziej znany jako Śmierć i dziewczyna.

Na rok 1994 przypada premiera kolejnego pełnometrażowego filmu polskiego reżysera, $\mathrm{w}$ którym ponownie pochyla się on nad muzyką klasyczną. Co więcej, autor Noża w wodzie znów wybiera Kwartet $d$-moll Schuberta. Sama programowość utworu jest tym razem istotniejsza niż w przypadku Co? - Śmierć i dziewczyna, to bowiem również tytuł samego filmu, a wyrażając się bardziej precyzyjnie - przeniesionej przez Polańskiego na duży ekran sztuki teatralnej Ariela Dorfmana. Chodzi tu zatem już nie tyle o muzykę, która mogłaby wywołać dodatkowe skojarzenia symboliczne, ile o utwór bardzo konkretny, z bardzo konkretnym tytułem, dodajmy - utwór, który niejako „ustawia” film.

Owa „konkretność muzyki w filmie” - fakt, że to akurat te a nie inne utwory, tego a nie innego kompozytora, wybrzmiewają na ekranie znajduje swój pełny wyraz w nagrodzonym Złotą Palmą i Oscarem Pianiście (2002). Wydaje się, że w odniesieniu do zagadnienia muzyki klasycznej w kinie Polańskiego to właśnie ten tytuł zasługuje na największą uwagę.

Muzykę rozbrzmiewającą w Pianiście można podzielić na trzy segmenty. Pierwszy i najważniejszy stanowiłaby muzyka Fryderyka Chopina, drugi - oryginalna muzyka filmowa skomponowana przez Wojciecha Kilara, oraz trzeci, na który składałyby się, pojawiające się jakby mimochodem, prekompilowane[3] utwory innych kompozytorów, przede wszystkim sonata Księżycowa Beethovena, Suita wiolonczelowa (No 1 BMV 1007) Jana Sebastiana Bacha oraz instrumentalna wersja piosenki Henryka Warsa Umówitem się z nia na dziewiata. Wróćmy zatem do muzyki klasycznej w jej romantycznej odsłonie - do muzyki Chopina. Jak pisze o niej Iwona Sowińska w kontekście postaci filmowego Szpilmana:

Dla bohatera filmu muzyka - wyłącznie muzyka Chopina - jest alternatywną rzeczywistością, zawsze pod ręką. Najpierw w scenie w kawiarni, gdzie przygrywa gościom: gra szlagier Henryka Warsa Umówiłem się $z$ nią na dziewiąta (z przedwojennej komedii Leona Trystana Piętro wyżej, 1937), lecz niepostrzeżenie zmienia tryb melodii na mollowy, by gładko

[3] Jak pisze Krzysztof Kozłowski: „Muzyka prekompilowana to tyle, co muzyka «już istniejąca», która nie została skomponowana do danego filmu, a której używa się z myślą o skompilowaniu z niej «nowej» muzyki”. Zob. K. Kozłowski, Stanley Kubrick. Filmowa polifonia sztuk, Wydawnictwo Naukowe PWN, Warszawa 2013, s. 181. Ów termin odnosi się - rzecz jasna - również do wykorzystanej w Pianiście muzyki Chopina. 
przejść do tematu pierwszej części Koncertu e-moll (nb. nie wymienionego w napisach końcowych). Potem, gdy się już ukrywa, muzyka towarzyszy mu tylko w wyobraźni. W jednej z kryjówek nie dotykając klawiszy "gra” fragment Poloneza Es-dur, a w opuszczonym szpitalu nawiedza go echo Ballady g-moll; zmaterializowanie się obu tych utworów (Ballady najpierw) zapowiada, a następnie potwierdza odwrócenie się złego losu[4].

To właśnie scena owego „zmaterializowania się” Ballady g-moll (No 1, op. 23) ujawnia głębokie znaczenie muzyki Chopina w Pianiście. Jest to moment, kiedy protagonista po raz pierwszy, ukrywając się, może, a nawet musi, fizycznie dotknąć klawiszy fortepianu. Momenty swoistego przejścia z rzeczywistości alternatywnej do prawdziwego życia, które reprezentowane są kolejno przez muzykę diegetyczną wewnętrzną („granie” w samotności bez dotykania klawiszy) i zewnętrzną (koncert dla Hosenfelda), zawsze jednak jest to ta sama muzyka Chopina. Pytanie, czy w obliczu zagłady aby na pewno brzmi ona tak samo jak dawniej? Jak pisze Mariola Dopartowa:

Niemiec nie czyni gry warunkiem czegokolwiek, niczego Szpilmanowi nie obieca. Gdy dowie się, kim jest ludzki robak po drugiej stronie pokoju, zaprowadzi go do fortepianu. Być może jest to jakiś jego własny eksperyment, swoista antycypacja pytania Adorna, w wersji: czy możliwa jest muzyka po getcie?[5]

Ale pytanie to Polański jeszcze dobitniej stawia właśnie w scenie „zmaterializowania się" drugiego utworu - Wielkiego Poloneza Es-dur (op. 22 - Allegro molto). Dlaczego Polański zdecydował się zakończyć film tym właśnie utworem i czy faktycznie w scenie finałowego koncertu mamy do czynienia z - jak pisało wielu krytyków - iście hollywoodzkim happy endem? Odpowiedzi na pytanie pierwsze po części udzielił Tadeusz A. Zieliński, tak oto pisząc o Grande polonaise brillante:

Wielki polonez, choć ukończony po wyjeździe kompozytora z kraju, reprezentuje - jako ostatnia z kompozycji koncertowych Chopina w stylu brillant - postawę estetyczną właściwą jego okresowi warszawskiemu. Ale ujawnia także przy tym własny, indywidualny profil stylistyczno-wyrazowy, wyróżniający się nawet na tle całej twórczości Chopina. Bogactwo i przepych dźwiękowych deseni, jak ze wschodniej tkaniny, oraz lekkość wirtuozowskich figur niosą z sobą uczucie pogody i szczęśliwości, a równocześnie ton bardzo miękkiego, wypełnionego czułością liryzmu. Przy tym wszystkim muzyka ta zawiera pewien odcień delikatnej fantastyki[6].

Władysław Szpilman gra Wielkiego Poloneza, utwór pogodny, a zarazem liryczny, związany z okresem warszawskim kompozytora, właśnie w stolicy, stolicy kraju wielkich romantyków, który jeszcze kilka miesięcy wcześniej przeżywał piekło wojny. Nasuwają się kolejne pytania: kim są ludzie na sali słuchający gry Szpilmana i jakie zadanie w powojennej rzeczywistości przypada muzyce Chopina. Jak pisze

[4] I. Sowińska, Chopin idzie do kina, Universitas,

Kraków 2013, s. 291.

[5] M. Dopartowa, Labirynt Polańskiego, wyd. 2,

Rabid, Kraków 2003, s. 253.
[6] T.A. Zieliński, Chopin. Życie i droga twórcza, PWM, Kraków 1993, s. 191. 
Mikołaj Jazdon: „Finałowa scena szopenowskiego koncertu fortepianowego (Szpilman gra Wielkiego Poloneza) w warszawskiej filharmonii symbolizuje ostateczny powrót do życia odbudowującego się miasta i ocalałych mieszkańców”[7]. Anna Śliwińska zauważa natomiast, że: „Koncert grany przez Szpilmana, być może przed tymi, którzy obojętnie mijali getto, rozgrzesza ich i pobudza do reakcji. Aplauz, jakim kończy się film, pokazuje, że nie ma już w tych ludziach obojętności, jest żywa reakcja"[8]. Czy zgromadzona w tej scenie na sali publiczność nie jest podobna do tej, która słucha Kwartetu d-moll Schuberta w Śmierci i dziewczynie? Oba filmy Polańskiego traktują przecież o zbrodniach, jakich ludzie dopuszczają się względem ludzi, zarówno w znaczeniu jednostkowym, jak i zbiorowym. Anna Śliwińska rozwija ów problem, stawiając kolejne pytanie:

[...] końcowe [ujęcia Pianisty - P.P.] prezentują bohatera występującego w Filharmonii Narodowej. Muzyka, która ocala duszę, pozwala także wybaczyć i trwać, mimo tragicznych zdarzeń. Skupione i zasłuchane audytorium być może składa się z tych samych Polaków, którzy niemo patrzyli na wysiedlenie Żydów. W Śmierci i dziewczynie zasygnalizowano podobny problem, aż nazbyt wyraźnie. Czy wolno i trzeba wybaczyć?[9]

Ostatnia scena Pianisty jest nie tyle happy endem, ile postawieniem pytania o sens - sens przebaczenia, sens sztuki i sens muzyki po getcie. Owa pogodność, liryczność i elementy fantastyki, o których pisał w kontekście Poloneza Tadeusz Zieliński, nadają skądinąd obrazowi Polańskiego nieco ironiczny wydźwięk. Po tym wszystkim, co reżyser „serwuje” widzowi przez większość czasu ekranowego, finałowa scena wydaje się raczej stanowić swego rodzaju przestrogę: „Słuchajcie Chopina, ale nie zapominajcie, do czego zdolny jest człowiek!". Jak pisze Mariola Dopartowa:

„Walka o Chopina” w Pianiście jest walką na bardzo różnych poziomach. Po pierwsze jest walką o duchową wolność, która zaczyna się tam, gdzie człowiek potrafi postawić sobie ograniczenia i gdzie w czasach „moralności tymczasowej" potrafi wcielić w życie proste zasady Kartezjańskiej samodyscypliny, jak rzeczywisty i filmowy Szpilman. Bez niej nie ma wolności odzyskanej na poziomie życia społecznego i historii, będących płaszczyzną, na której człowiek zawsze dąży do odebrania wolności drugiemu. Po drugie, jest walką o żywą treść ludzkiego doświadczenia, która pojawia się tylko wtedy, gdy dokonujemy „żywych” moralnych wyborów, wpisujących się na autentyczną materię naszego życia. Tylko wtedy Chopinowski Polonez Es-dur nie stanie się chocholim tańcem, jak kaleczony przez zbieraninę muzyków i przypadkowych muzykantów Polonez A-dur w Popiele i diamencie[10].

Podsumowując funkcję Grande polonaise brillante w Pianiście, warto poruszyć również kwestię samego filmowania koncertu, który

[7] M. Jazdon, Zagłada miasta. Warszawa $w$ Pianiście Romana Polańskiego, „Images”, vol. XII, nr 21, 2013, s. 90-91.
[8] A. Śliwińska, Pianista - obraz getta w filmowym języku Romana Polańskiego, „Images”, vol. IX, nr 17-18, 2011, s. 54.

[9] Ibidem, s. 55.

[10] M. Dopartowa, op. cit., s. 250. 
wykonywało notabene na ekranie dwóch artystów - Adrien Brody (odtwórca głównej roli) oraz Janusz Olejniczak (wykonawca muzyki Chopina, którą słyszymy w filmie). W niezwykle ciekawy sposób wypowiedział się na ten temat Tadeusz Strugała, polski dyrygent, który czuwał nad przebiegiem zgrywania muzyki do filmu Polańskiego:

Adrien Brody tylko w jednej scenie, kiedy jako Szpilman musi udowodnić niemieckiemu oficerowi, iż jest muzykiem, sam zagrał początek Chopinowskiej ballady. W innych momentach zastępował go Janusz Olejniczak, którego ręce będzie widać na ekranie. Pianista kończy się występem bohatera w Filharmonii w Warszawie, kiedy gra on Wielkiego Poloneza [...]. Podczas filmowania tego koncertu najpierw do fortepianu zasiadł Adrien Brody, potem dubler, czyli Janusz Olejniczak. Dla mnie fascynujące było obejrzenie jak dzięki obróbce komputerowej w filmowym obrazie następowało nakładanie nie tylko ich dłoni, ale także całych sylwetek, bo przecież wiadomo, iż każdy, kto siada do instrumentu, porusza się przy nim we własny, indywidualny sposób[11].

Równie ważnym, a może nawet jeszcze ważniejszym utworem Chopina, wykorzystanym w Pianiście, jest Nokturn cis-moll (Posthumous), który pełni w filmie Polańskiego funkcję klamry kompozycyjnej. Podobnie jak w przypadku Wielkiego Poloneza Es-dur, mamy w tych scenach do czynienia z nakładaniem się sylwetek Olejniczaka i Brody’ego. Pierwsze barwne[12] ujęcie Pianisty to właśnie zbliżenie na dłonie polskiego laureata Konkursu Chopinowskiego, wygrywające pierwsze takty utworu Chopina. Obserwujemy powolny, dostosowany do tempa utworu, ruch kamery w górę, po czym widzimy twarz skupionego Adriena Brody'ego.

Scena, o której mowa, to bodaj najciekawszy w całej twórczości Polańskiego przykład niezwykle twórczego wykorzystania zaledwie dwóch elementów ścieżki dźwiękowej - muzyki i efektów szmerowych, w odniesieniu do treści filmu. Jak pisze o Nokturnie cis-moll Tadeusz Zieliński:

Chopin odszedł tu od prostej, łatwo uchwytnej melodyjności, właściwej wcześniejszym nokturnom i posłużył się tematami o bardziej wyszukanym rysunku i budowie frazy. Dotyczy to zwłaszcza [...] Nokturnu cis-moll,

[11] T. Strugała, Nuty na każda sekundę, rozm. J. Marczyński, „Rzeczpospolita” 2002, 5 września (nr 207), s. A9.

[12] Nokturn rozbrzmiewa już w introdukcji filmu, na którą składają się archiwalne ujęcia przedstawiające przedwojenną Warszawę. Jak pisze Mikołaj Jazdon: „Sekwencja [...] została zbudowana $\mathrm{z}$ jedenastu czarno-białych archiwalnych ujęć, pokazujących przedwojenne obrazy śródmieścia stolicy Polski. Współczesny widz odczytuje je zapewne jednak przede wszystkim jako pewien konwencjonalny chwyt, nierzadko stosowany w początkowych fragmentach filmów fabularnych, polegający na wykorzystaniu dokumentalnych zdjęć i kronikalnych ujęć dla wpro- wadzenia odbiorcy w klimat historycznych wydarzeń, o których film opowiada w swej dalszej części. Twórca niejako powołuje się w ten sposób na autorytet dokumentalnych obrazów, licząc, że ich autentyzm będzie w jakiejś mierze promieniował na wizerunek przeszłości stworzony w dalszych partiach filmu. W przypadku Pianisty zasadne jest jednak odczytanie sekwencji otwierającej film nie tylko jako nawiązania do konwencji, ale także jako wprowadzenia wątku historii zagłady Warszawy, który prowadzony jest w filmie równolegle, tak jakby miasto było drugim obok Władysława Szpilmana - głównym bohaterem filmu". M. Jazdon, op. cit., s. 77. 
utworu owianego nastrojem mrocznym i posępnym, pełnego tajemniczości i tragizmu - jak dotąd nokturnu chyba najgłębiej przeżytego przez Chopina. Melodia jest tu bardzo oszczędna; wyłania się jakby niezdecydowanie $\mathrm{z}$ brzmienia harmonicznego, przez chwilę zarysowuje jakiś wyraźny motyw i znów zamiera[13].

Mikołaj Jazdon tak oto omawia z kolei funkcje następujących po sobie eksplozji, które w końcu ostatecznie przerywają występ Szpilmana w studiu Polskiego Radia.

[...] wybuch bomby w studiu radiowym przewraca grającego Szpilmana i niszczy jego fortepian. Eksplozja staje się tu metaforą wybuchu wojny, a zarazem pierwszego etapu niszczenia Warszawy, w którym ulegają likwidacji instytucje państwa polskiego, dokonany zostaje brutalny zamach na kulturę podbitego kraju. Przypomina się powiedzenie: „gdy grzmią działa, milkną muzy"[14].

Aby jednak w pełni docenić kunszt reżyserski przywołanej sceny, niezbędne jest bardziej wnikliwe spojrzenie na relacje już nie tylko warstwy wizualnej oraz audialnej, ale właśnie na to, w jaki sposób muzyka i szmery funkcjonują w obrębie tej drugiej.

Nokturn cis-moll, poprzez - parafrazując Tadeusza Zielińskiego - melodię wyłaniającą się jakby niezdecydowanie, ma sam w sobie niezwykle ciekawą dramaturgię. Dramaturgia ta przeszczepiona zostaje niejako również na grunt filmu. Chopin i Polański wspólnie przygotowują widza i zarazem słuchacza na coś, co w tajemniczy sposób wyłania się z tej spowitej tragizmem i tajemniczością muzyki. Jak pisze dalej Tadeusz Zieliński o Nokturnie: „Pomysł powtórzenia tematu z dodanym drugim głosem (t. 20-26) odsłania jego głębszy sens i wzmacnia zawartość uczuciową; kolor staje się bardziej nasycony, a wyraz bardziej natarczywy"[15]. To właśnie pomiędzy taktem 20 a 26 (kulminacja w t. 24) dochodzi do eksplozji, która przerywa koncert Pianisty. Chwila, na którą z niezwykłą pieczołowitością przygotowuje słuchacza Chopin, staje się w filmie Polańskiego, dość przewrotnie - parafrazując Mikołaja Jazdona - momentem brutalnego zamachu na polską kulturę.

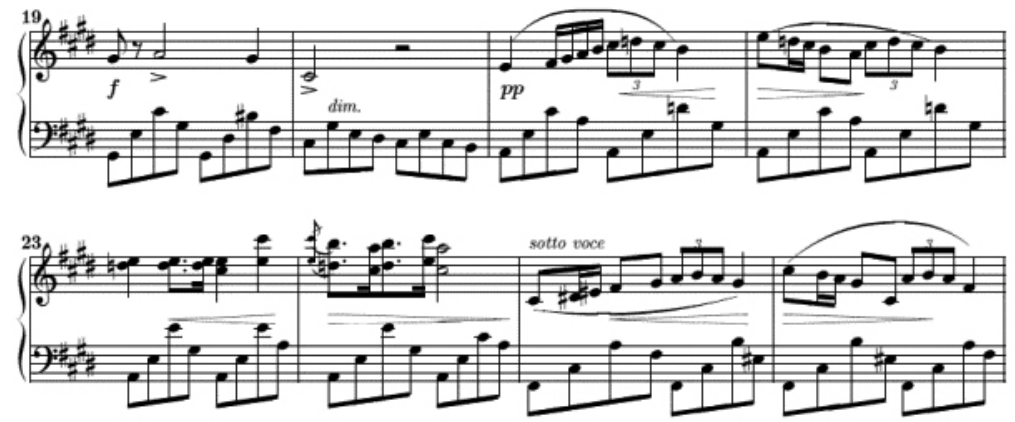

[13] T. Zieliński, op. cit., s. 357.

[15] T. Zieliński, op. cit., s. 358.

[14] M. Jazdon, op. cit., s. 88. 
Bomby trafiają - mówiąc metaforycznie - dokładnie w te nuty, o które chodzi Polańskiemu, aby wywołać odpowiednią reakcję emocjonalną widza. Ale nie chodzi tylko o nią. W scenie pozbawionej dialogów, niezwykle ascetycznej w odniesieniu do obrazu, reżyser tworzy paradoksalnie najbardziej chyba wymowną pod względem zawartych $\mathrm{w}$ filmie treści ilustrację, $\mathrm{z}$ - powracającym na prawach lejtmotywu pytaniem Teodora Adorno włącznie. Nie można na koniec tych rozważań nie zacytować samego Romana Polańskiego, którego wypowiedź wydaje się - z punktu widzenia reżyserskiego rzemiosła - dobrze pasować do przeanalizowanej powyżej sceny:

[...] czasem okazuje się, że niektóre sceny mają w sobie większy potencjał, niż przewidywałem [...]. Wyobraź sobie, że potrzebujesz krótkiego ujęcia pokazującego papierosa trzymanego między palcami bohatera. Niektórzy reżyserzy po prostu dadzą aktorowi do ręki papierosa i sfilmują go - i już, cała operacja zajmie kilka minut. Ale może ujęcie byłoby ciekawsze, gdyby na końcu papierosa wisiał długi słupek popiołu, opadający na ziemię w odpowiednim momencie[16].

Polański to reżyser nie tylko obrazu, ale również dźwięku, co więcej - reżyser niezwykle świadomy faktu, że film to także sztuka czasu, a scenariusz filmowy musi niekiedy stać się partyturą, zwłaszcza jeśli tematem filmu jest muzyka. „Rozstrzelany” 24 takt Nokturnu cis-moll jest ( $\mathrm{z}$ punktu widzenia trafienia w odpowiedni akcent w filmie) tym, czym wspomniany powyżej moment opadnięcia słupka popiołu z papierosa - jest znakomitym wyczuciem muzycznej frazy.

Polański, jak się wcześniej rzekło, powróci do Nokturnu cis-moll w jednej z ostatnich scen filmu, która stanowi swego rodzaju lustrzane odbicie tej pierwszej - fortepian znajduje się teraz po prawej stronie kadru. Szpilman ponownie zasiada do instrumentu, by „dokończyć” swój występ sprzed wojny. Istotne, w powiązaniu ze sceną otwierającą film, jest tym razem nie tylko to, co jest, ale też to, czego nie ma. Gdy Pianista zbliża się do 24 taktu Nokturnu, jego oczy poczynają napełniać się łzami. Eksplozję, która kiedyś przerwała występ Szpilmana, zastąpiło głębokie wzruszenie. Czy doświadczenie okrucieństwa wojny mogło paradoksalnie - wchodząc w polemikę z Teodorem Adorno - wzbogacić duszę artysty? Trudno stwierdzić, czy zamiarem Polańskiego było postawienie takiego pytania, nie można jednak powiedzieć, że nie nasuwa się ono po obejrzeniu tej sceny. Być może prawdziwą wartość muzyki Chopina są w stanie docenić ci, którzy - parafrazując Mariolę Dopartową - musieli stoczyć o nią wielopoziomową walkę.

Ale Chopin posłużył również Polańskiemu do zilustrowania wątku, który bardziej niż z problemem „zamachu” na polską kulturę wiąże się z tematem rozdzielenia ludzi, którzy, gdyby nie koszmar wojny, mogliby stać się dla siebie najważniejszymi osobami na świecie.

[16] Cyt. za: F.X. Feeney, Roman Polański, tłum. J. Halbersztat, pod red. P. Duncan, Taschen, Köln 2006, s. 144. 
Wątek ten, za sprawą wyrafinowanych zabiegów reżyserskich, przewija się - dość subtelnie - przez znaczną część filmu. Mikołaj Jazdon wiąże go z powtarzanym w filmie, tak jak muzyka Chopina, motywem wizualnym - motywem pewnej uliczki:

Po raz pierwszy pojawia się ona w scenie randki Władysława Szpilmana z Dorotą, piękną wiolonczelistką, którą poznał podczas bombardowania rozgłośni radiowej. [...] Obraz tejże uliczki, sfilmowany nieomal w identyczny sposób, powraca w filmie dwukrotnie. Po raz pierwszy w scenie, gdy po wydostaniu się z getta Szpilman w swoim mieszkaniu-kryjówce siada do fortepianu. Przesuwa bezszelestnie palcami ponad klawiaturą instrumentu, wywołując w myślach muzykę, której nie może zagrać. Wówczas pojawia się obraz opustoszałej uliczki w zimowej scenerii z padającymi płatkami śniegu. Ostatni raz uliczka ukazuje się w myślach Szpilmana, gdy ponownie przebiera palcami w powietrzu, jakby grając na niewidzialnym fortepianie, gdy wycieńczony siedzi na taborecie w opuszczonym przez Niemców szpitalu po upadku powstania warszawskiego. [...] Dlaczego pianista pragnie oczami wyobraźni widzieć akurat to miejsce, ilekroć nachodzi go pragnienie ponownego grania muzyki? Być może powraca wówczas do ostatnich najpiękniejszych chwil, jakie przeżył, nim przypadł mu w udziale ponury wojenny los? Sceny z początku filmu, w których oglądamy spotkania Władka i Doroty, pokazują uczucie rodzące się między parą artystów. Ich spacer uliczką Starego Miasta jest inicjacją tej relacji, która nie będzie miała dalszego ciągu. Kiedy Władek spotka Dorotę po ucieczce z getta, będzie ona już żoną innego i przyszłą matką, oczekującą narodzin dziecka[17].

Muzyka, o której pisze Jazdon, to oczywiście Chopin - Wielki Polonez Es-dur oraz Ballada g-moll, muzyka, którą - parafrazując Iwonę Sowińską - główny bohater ma zawsze pod ręką. To właśnie na pięknie wykonywane przez Władka utwory Chopina powołuje się Dorota, aby zwrócić na siebie uwagę Pianisty w pierwszych scenach filmu. Muzyka romantyzmu staje się zatem przyczynkiem do romansu pomiędzy parą... muzyków. Być może dlatego właśnie Polański każe wykonać Dorocie Suite wiolonczelowa Jana Sebastiana Bacha, kiedy dochodzi do ponownego spotkania bohaterów. Nadzieję na romantyczną miłość zastąpiła barokowa posępność. Główny bohater ocalał, ale wątek jego i Doroty jako pary kochanków został definitywnie zamknięty.

Wypaczenie? Sentymentalizm? Patetyczna przesada? Nic z tych rzeczy - Polański nie wpadł w żadną z pułapek, przed którymi przestrzegał Bohdan Pociej w odniesieniu do ryzyka, jakie wiąże się z wykorzystywaniem w filmach fabularnych pereł muzyki klasycznej. Zaledwie cztery utwory Chopina wystarczyły reżyserowi, by w twórczy i inteligentny sposób opowiedzieć historię człowieka, który przeżył wojnę, dlatego że był muzykiem. Nie ma w Pianiście sceny ani ujęcia, utworu ani nawet jednego krótkiego fragmentu partytury potraktowanego w filmie bez należytej powagi i czci. Wielka muzyka w wielkim filmie. Tak chyba należałoby podsumować te rozważania.

[17] M. Jazdon, op. cit., s. 87 . 
Muzyka klasyczna towarzyszy Romanowi Polańskiemu od najwcześniejszych szkolnych etiud. Niemniej, we wczesnych fazach twórczości wchodzi ona do filmowego świata polskiego reżysera jakby tylnymi drzwiami, nie skupiając na sobie zbyt dużej uwagi. Stanowi delikatne akustyczne tło dla apartamentowych scen Diamentowego naszyjnika oraz Dziecka Rosemary (Beethoven). Z czasem jednak jej znaczenie zaczyna być coraz wyrazistsze. W komedii Co? Polański korzysta $z$ utworów Schuberta, Beethovena i Mozarta w sposób ciekawy i nieuwłaczający, ale jeszcze nie wysoce artystyczny. Dopiero w Śmierci i dziewczynie Schubert wybrzmiewa w pełnej krasie, tak jakby Kwartet $d$-moll został skomponowany dosłownie na potrzeby tego filmu. Ale to Pianista jest muzycznym zwieńczeniem wszystkich prób reżysera związanych z wykorzystywaniem w dziele filmowym muzyki klasycznej. Przy tak wielkim znaczeniu Chopina, który na wieki zapisał się w pamięci zbiorowej Polaków, jeden niewielki błąd mógł mieć swoje przełożenie na kompletną filmową katastrofę. Tak się jednak nie stało, ponieważ uratowała Polańskiego jego wielka kultura muzyczna i nienaganne filmowe rzemiosło. Po Pianiście polski reżyser nie sięgnął już ani po Chopina, ani po żadnego innego wielkiego klasyka reprezentującego „centrum europejskiej kultury muzycznej”[18], być może Polański był i jest świadomy faktu, że dalej już po prostu pójść się nie da.

[18] Wyjątek stanowi, wyreżyserowana przez Polańskiego, reklama kosmetyków „Greed”, w której reżyser w humorystyczny sposób wykorzystał Preludium
C-dur (No 1, op. 28 ) Chopina w wykonaniu Rafała Blechacza. 